International Journal of Current Advanced Research

ISSN: O: 2319-6475, ISSN: P: 2319 - 6505, Impact Factor: SJIF: 5.995

Available Online at www.journalijcar.org

Volume 6; Issue 4; April 2017; Page No. 3137-3138

DOI: http://dx.doi.org/10.24327/ijcar.2017.3138.0203

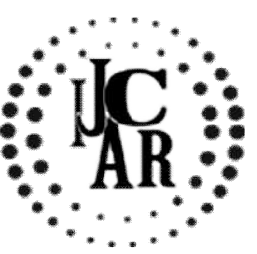

Research Article

\title{
KNOWLEDGE, ATTITUDE AND PRACTICE REGARDING THE USAGE OF NEEDLE DESTROYERS IN GENERAL DENTAL PRACTICES
}

\author{
Suhas Manoharan., Dhanraj and Ananthi.T
}

Department of Prosthodontics Saveetha Dental College and Hospitals No.162, PH road, Chennai-600077

\begin{tabular}{l}
\hline A R T I C L E I N F O \\
Article History: \\
Received $13^{\text {th }}$ January, 2017 \\
Received in revised form $19^{\text {th }}$ February, 2017 \\
Accepted $22^{\text {nd }}$ March, 2017 \\
Published online $28^{\text {th }}$ April, 2017
\end{tabular}

Key words:

Knowledge, Attitude And Practice

\begin{abstract}
A B S T R A C T
Aim: To survey knowledge, attitude and practice regarding the usage of needle destroyers in general dental practices.

Background: Needle destroyers are devices used electrically burn and cut needles. In developing countries, there is still a need for needle safety in hospital settings as most of the needle removal processes are done manually and under severe risk of needle stick injury. This lowers possible pathogen spread by preventing the reuse of the syringes, reducing incidents of accidental needle-sticks, and facilitating syringe disposal.

Methodology: A survey was taken among 70 dental practitioners of various specialities. The questionnaire was used to check the attitude of dentists and their opinion about the quality and efficiency of needle destroyers. The questionnaire was created using Survey planet, a survey-tool app.

Conclusion: About $65 \%$ surveyed were aware of needle destroyers but never used it. Among them $56 \%$ claimed to have gained knowledge regarding needle destroyers from friends or associates. Hence, there is need to create awareness regarding the usage of needle destroyers among the general Dental practitioners.
\end{abstract}

Copyright $\mathrm{O} 2017$ Suhas Manoharan., Dhanraj and Ananthi.T. This is an open access article distributed under the Creative Commons Attribution License, which permits unrestricted use, distribution, and reproduction in any medium, provided the original work is properly cited.

\section{INTRODUCTION}

Needle destroyers are devices used to destroy disposable needles by cutting the syringe nozzle. The device has a cannula cutter and a hub that are joined at a slidable joint and pivoted at a non axial pivot point. ${ }^{[1][3][5]}$

Major composition of medical waste is are needles and hypodermic syringes. Safe disposal of such wastes is a challenging task. ${ }^{[2]}$ Needle stick injuries are also a common incidence in the medical field. Estimates indicate that 600,000 to 800,000 such injuries occur annually, about half of which go unreported. ${ }^{[4]}$ needlestick injuries have the ability to transmit bacteria, protozoa, viruses and prions ${ }^{[4]}$. Needle destroyers reduce the instances of accidental needlesticks injuries because they allow immediate removal and containment of the needles, especially if the device is near the area of use. Reuse of syringes is prevented because the needle-remover physically separates the needle from the syringe, making the syringe useless. They also improve waste disposal by decreasing both the amount of infectious waste and the amount of safety boxes needed for the waste, since safety boxes can pack syringes $20-60 \%$ more compactly without the needles.

*Corresponding author: Suhas Manoharan Department of Prosthodontics Saveetha Dental College and Hospitals No.162, PH road, Chennai-600077
This study aims to summarize the current state of knowledge, attitude and practice of needle destroyers among general dental surgeons and also create an awareness.

\section{MATERIALS AND METHODS}

A cross sectional survey was conducted among 70 dental practitioners in Chennai. The questionnaire was used to check the attitude of dentists and their opinion about the quality and efficiency of needle destroyers. The questionnaire was created by using a survey-tool app, Survey Planet (https://app.surveyplanet.com/\#). The subjects were administered with a structured questionnaire consisting of questions on their knowledge, attitude and awareness of needle destroyers.

\section{Questionnaire}

- Are you familiar of needle stick injuries?

- Are you aware of the blood borne diseases transmitted by needle?

- How familiar are you with needle destroyers

- Which of these needle removers have you used?

- How did you first hear about needle removers?

- Overall, how do you rate the quality and use of needle destroyers?

- Would you recommend needle destroyers to a friend or associate? 
- How likely are you to buy needle destroyer in the future?

\section{RESULTS}

The data collected was analysed and tabulated along with suitable explanatory chart. About $71 \%$ of the dentists rated the quality of needle destroyers as good, whereas only a mere $6 \%$ use it regularly. However, $65 \%$ of the dentists where aware but never used it. $56 \%$ of them learnt of needle destroyers through friends, $21 \%$ through Internet and 12\% through magazines.

\section{DISCUSSION}

This study was conducted to assessknowledge, attitude and practice regarding the usage of needle destroyers in general dental practices. From the survey taken various inferences can be drawn. A majority of dental practitioners about $65 \%$ of them were aware of needle destroyers but haven't used the instrument. This may be due to cost and availability of the device. $56 \%$ of the dental surgeons claimed to have gained knowledge regarding needle destroyers through associates or friends, $21 \%$ of dentists through internet and the remaining through newspapers and magazines.

Most dental practitioners gave positive reviews regarding the instrument and promised to buy a needle destroyer in future. Needle stick injuries are a common incidence in medical practices $^{[4]}$. The needle stick may serve as mode of transmission of many blood borne diseases such asHIV and hepatitis ${ }^{[8][9]}$. Hence, proper disposal and handling of the needle is essential. Most dentists remove and bend the needle manually from the syringe and then dispose it which is a bad practice. Even wearing dual latex gloves doesn't guarantee protection against pathogens. Usage of needle destroyers ensures maximum protection against pathogens and also injuries $^{[7]}$. Also, ensures a easier and safe disposal of needles. About 800,000 injuries occur annually due puncture of the epidermis of the skin due to syringes and about half of which go unreported. ${ }^{[4]}$ There a is a huge possibility transmission of bacteria, protozoa, viruses and prions ${ }^{[4]}$. Disposal of such wastes known sharp wastes is also difficult. Sharp waste disposal is done by autoclaving. ${ }^{[2]}$ Incineration is also an unorthodox method of safe disposal but isn't preferred. Only chemotherapy sharps are disposed by incineration.Most hospitals dispose wastes by sealing the needles in a container ensuring minimum contact. Usage of Needle destroyers in clinical environment reduce the instances of accidental needle-sticks injuries because they allow immediate removal and containment of the needles. It paves way for easier sharps disposal, lesser pathogen spread and can reduce the occurrence of needle stick injuries.
Also, it ensures that needles are reuse and decreases the need for safety boxes for its disposable. Limitation of this device is that it requires two hands for its usage and in an hospital environment it may not be possible at all times which may cause exposure of the needleposing a risk to health care workers. Moreover, these devices are expensive and not readily available in all markets around the world. Hence, it may prove too expensive for many medical and dental professionals. Increased awareness and knowledge regarding needle destroyers will ensure better availability of the device and reduce drastically the occurrence of needle stick injuries among health care professionals

\section{CONCLUSION}

A majority of the dental practitioners about $65 \%$ surveyed were aware of needle destroyers but never used it and $56 \%$ of them claimed to have gained knowledge regarding needle destroyers from friends or associates. Hence, there is need to create awareness regarding the usage of needle destroyers among the general Dental practitioners.

\section{Reference}

1. Choksi, Pradip V., William D. Christoffel, and Christopher JC Edwards. "Needle destroyer with improved mechanical advantage." U.S. Patent No. 4,255,996. 17 Mar. 1981.

2. Rao, S. K. M., et al. "Biomedical waste management: an infrastructural survey of hospitals." Medical Journal Armed Forces India 60.4 (2004): 379-382.

3. Pepper, Kenneth V. "Syringe and needle disposal system." U.S. Patent No. 4,488,643. 18 Dec. 1984.

4. Rice, J. J., J. P. McCabe, and F. McManus. "Needle stick injury." International orthopaedics 20.3 (1996): 132-133.

5. Stevens, Carlile R. "Syringe and needle destruction device." U.S. Patent No. 6,621,031. 16 Sep. 2003.

6. Bains, Harmesh S., and Deepak Bhat. "Safe Injection Practices." recent advances in pediatrics-17: 346.

7. Muller, Nancy, et al. "Evaluating the use and acceptability of a needle-remover device in India." Tropical doctor 37.3 (2007): 133-135.

8. Murphy, Maria. "Needle-stick injuries." Australian Nursing and Midwifery Journal 11.7 (2004): 41.

9. Gallacher, W. "Needle stick injuries." Canadian Journal of Anesthesia/Journal canadien d'anesthésie 39.5 (1992): 518-519.

\section{How to cite this article:}

Suhas Manoharan et al (2017) ' Knowledge, Attitude And Practice Regarding The Usage Of Needle Destroyers In General Dental Practices', International Journal of Current Advanced Research, 06(04), pp. 3137-3138.

DOI: http://dx.doi.org/10.24327/ijcar.2017.3138.0203 